\title{
Constraints Faced by the Young Entrepreneurs Involved in Dairying Enterprise in Semi-arid Dholpur District of Rajasthan
}

\author{
Sandeep Sharma, Sanjeev Kumar Singh, Amit Singh* and Rashmi
}

Department of Veterinary \& Animal Husbandry Extension Education, College of Veterinary

Science and Animal Husbandry, U.P. Pt. Deen Dayal Upadhyaya Pashu Chikitsa Vigyan

Vishwavidyalaya Evam, Go-Anusandhan Sansthan, Mathura, Uttar Pradesh, India

*Corresponding author

\section{A B S T R A C T}

\section{Keywords}

Constraints, Dairy

Enterprise,

Entrepreneurs,

Rajasthan, Youth

Article Info

Accepted:

08 December 2020

Available Online:

10 January 2021
The study examined the constraints faced by the youth involved in dairy farming as an entrepreneur. Dairy industry with a large number of young dairy entrepreneurs in rural areas is making a tremendous impact on the milk production of the country. The primary data were collected from 120 young randomly respondents from Dholpur district, Rajasthan. The young dairy entrepreneurs facing constraints were recorded into six categories viz., personal \& social, credit support/financial, infrastructural, administrative, technical and marketing by the help of pretested structured interview schedule. The young entrepreneur faces various constraints in running the enterprise i.e. non-remunerative price of milk, non-functioning milk cooperative societies, high cost of concentrate, lack of subsidies as the major constraints. Therefore measures must be adopted to enhance the adoption of animal husbandry technologies by launching new capacity building programme especially targeting rural youth. In order to increase production, it is necessary to impart training on regular basis to youth for adoption of new animal husbandry technologies which can be utilized and adopted by the youth to their full advantage.

\section{Introduction}

Youth represent the most dynamic and vibrant segment of the population. India is one of the youngest nations in the world, with about 65 percent of the population under 35 years of age. The youth in the age group of 15-29 years comprise 27.5 percent of the population (Ministry of youth affairs \& sports 2018 19). United Nations defines 'youth' as persons between 15 and 24 years of age. 'Youth' was defined as a person of age ranging between 13-35 years, but in the current Policy Document, the youth agegroup is defined as 15-29 years with a view to have a more focused approach (National Youth Policy 2014). The word 'entrepreneur' is derived from the French verb 'enterprendre' which means, "to undertake". The entrepreneurs are key persons of any country for promoting economic growth and technological change. Government of India initiated a number of entrepreneurship development programmes \& schemes in 
agriculture, dairying and allied sectors. The Indian dairy industry with a large number of dairy entrepreneurs in rural areas has made a tremendous impact on the agrarian economy of the country. Dairying is not only an indispensable component of agriculture, but is also play crucial role for providing employment among the rural youth, to improve the socio-economic status and generate more income. Improved managemental practices have been prescribed by various research and development organizations to improve the dairy production but the farmers face various constraints in adoption of these practices (Meena et al., 2015). Constraints can be implied here to quote the problems or hindrance faced by dairy farmers while adopting day-to-day animal husbandry practices in their dairy enterprises (Akash et al., 2020). Keeping these aspects in view, the study was planned to focus on constraints faced by rural youth entrepreneur involved in animal husbandry practices.

\section{Materials and Methods}

Ex Post facto research design will be used for conducting the study since the variables chosen had already been occurred.The present study was conducted in Dholpur district of Rajasthan. Dholpur district was purposively selected because it has lowest livestock population compared to other district, so the study was conducted to identify the constraints which hinders youth for adopting improved animal husbandry practices. A total of 120 young respondents were selected from all the five blocks of the district. Constraint, which is operationalized as to analyze something that imposes a limit or restriction or that prevents something from occurring. During the course of the present investigation, the respondents expressed a number of constraints which were grouped into six categories viz., personal \& social, credit support/financial, infrastructural, administrative, technical and marketing. Primary information was collected by using a pretested structured interview schedule. The young dairy entrepreneurs facing constraints of animal husbandry practices and their responses was collected in three continuum viz, SA (Strongly agree), A (Agree), D.A. (Disagree) and were given scores as 2,1 and 0 respectively. After duly recording their judgments, the statements were considered for the analysis by calculating their weighted mean scores (WMS).

Weighted Mean Score $=\frac{\text { (Actual scores obtained for the statement) }}{\text { Maxi possible scores obtainable for the statement }}$

The weighted means score of the statement was calculated and the statements were ranked accordingly. The collected data was analyzed with help of suitable statistical test on the basis of mean weighted scores and ranking.

\section{Results and Discussion}

\section{Personal and Social constraints}

The major constraint faced by the rural youth is fear of failure since an enterprise involves risk as well as uncertainties followed by lack of family support, which is considered as vital for the success of the enterprise. However lack of awareness and lack of education in respect to establishment of livestock enterprise in rural areas vis-à-vis financial support from institution was lacking among the respondents. Further it was found that the rural youth have lack of knowledge in management of dairy farm, lack of other successful enterprises in rural areas and risk of theft was found to be the constraints among the rural youth. Similar findings were also reported by Balaganoormath et al., (2018) and Kumar et al., (2017). 


\section{Credit Support / Financial constraints}

The major constraint allocated by respondents was difficulties in getting loan from the financial institutions reveals that the rural youth does not have proper knowledge of availing loans as well as schemes of state/central government. Inadequate loan facility, high investment was ranked as second and third major constraint by the respondents. However high rate of interest charge by money lenders, unfavorable behavior of banking personals, exhaustive paper work in getting loan, uncertainty of loan for productive purpose were other constraints. It reveals that respondents get rid of money lenders and do not want to avail loan from them due to their high interest rates, but on the other hand their educational backgrounds hinder them in availing bank loan facilities. Hence there is a necessity to provide regular training programme among the rural youth to provide them information of banking formalities. Similar finding were also reported earlier by Khokhar (2007) and Patel et al., (2015).

\section{Infrastructural constraints}

High cost of initial investment in farm construction of building was ranked as the major constraint followed by non-availability of organized market, high cost of equipment's, high cost of farm labours and inadequate transport facilities. It reveals that high initial investment in establishment of an enterprise and timely unavailability of loan from government agencies and unavailability of market for selling the produce were found to be the major hindering factors in establishment of livestock enterprise by the rural youth. They continuously require the revolving fund for purchase of raw material, for payment to labour, purchase /repair of equipment's and inadequate fund of low hinders further development of enterprises.
These findings were in correlation as reported previously by Naik and Sumangla (2014), Kumar et al., (2017) and Balaganoormath et al., (2018).

\section{Administrative constraints}

In this aspect lack of expert's advice was identified as the major constraint followed by inadequate training facilities, defunctioning of milk cooperative societies, lack of subsidies, lack of institutional support, no extra incentive for clean milk production and absence of price fixing agency as other constraints it reveal that the government agencies must provide some incentive to those livestock owners who produce clean milk as per norms of the government. Similarly livestock owners must be provided subsidies in equipment's purchase as well as in taxes. Defunctioning of milk cooperative societies was also a major concern of livestock owner in selling of their produce on government rates, since unavailability of such facilities propelled them to sell their products to the middlemen on very low prices. Similar findings were also reported earlier by Mande and Thombre (2009), Rathod et al., (2011) and Dubey et al., (2012),

\section{Technical constraints}

Major technical constraints as informed by the respondents is high cost of concentrate followed by high cost of crossbreed cow/ improved buffalo, shortage of feed \& fodder, non-availability of green fodder, high cost of veterinary medicines, poor services availability at AI centre, inadequate knowledge of scientific feeding of dairy animals are other constraints faced by rural youth in running livestock enterprise in rural areas. It reveals that government should take necessary steps in providing training to rural youth for preparation of concentrate, preparation of mineral mixture, etc at their 
farm itself and thereby a big saving can be performed by the rural youth. Similar steps must also be undertaken for alternative arrangements of green fodder to mitigate the shortage of feed $\&$ fodder for their livestock and they must be trained for hay and silage making training to fulfill such shortages. Government must also take steps for upliftment of artificial insemination facilities at veterinary hospitals, so that services may be available within their villages at proper time of heat. Similar findings were also reported earlier by Singh et al., (2015) and Dubey et al., (2012).

\section{Marketing constraints}

Non-remunerative price for milk was identified as the major constraint among the respondents followed by non-functioning milk cooperative societies, delay in payment from customers, fluctuation of milk production, spoilage of milk due to delay in market, high cost of transportation and difficulty in distribution of milk in rainy season as other constraints related to marketing practices. Hence government must take steps for fixing price policy for milk \& its products so that each livestock owner may be able to get a handsome profit (Panchbhai et $a l ., 2017)$. Steps must also be undertaken to form self-help groups for milking purposes only in order save manpower and save profitability. Stress must be given to sell milk \& milk product in city vicinity areas on rotational basis among the group members, which enables an individual to engage himself for only three days in a month and other time may be utilized by him for other entrepreneurial activities. Similar findings were also reported by Dubey et al., (2012), Varaprasad et al., (2013) and Rathod et al., (2011).

Table.1 Personal \& SocialConstraints faced by rural youth involved in Animal Husbandry

\begin{tabular}{|c|l|c|c|}
\hline Sr. No. & Constraints & WMS & Rank \\
\hline 1. & Lack of education of rural youth & 91.25 & 4 \\
\hline 2. & Lack of awareness in rural area & 93.33 & 3 \\
\hline 3. & Lack of knowledge how to manage dairy farm & 79.17 & 5 \\
\hline $\mathbf{4 .}$ & Fear of failure because of more risk \& uncertainty & 95.83 & 1 \\
\hline $\mathbf{5 .}$ & Lack of family encouragement & 95.42 & 2 \\
\hline 6. & Theft / Predators & 64.58 & 7 \\
\hline 7. & Lack of successful enterprises in locality & 75.42 & 6 \\
\hline
\end{tabular}

Table. 2 Credits/financial constraints faced by rural youth involved in Animal Husbandry

\begin{tabular}{|c|l|c|c|}
\hline Sr. No. & Constraints & WMS & Rank \\
\hline 1. & High investment & 92.50 & 3 \\
\hline 2. & Inadequate loan facilities & 93.33 & 2 \\
\hline 3. & High rate of interest charge by money lenders & 91.67 & 4 \\
\hline $\mathbf{4 .}$ & Exhaustive paper work in getting loan & 71.25 & 6 \\
\hline $\mathbf{5 .}$ & Unfavorable behavior of banking personals & 90.42 & 5 \\
\hline 6. & Difficulties in getting loan & 94.58 & 1 \\
\hline 7. & Uncertainty of loan for productive purpose & 70.00 & 7 \\
\hline
\end{tabular}


Table.3 Infrastructural constraints faced by rural youth involved in Animal Husbandry

\begin{tabular}{|c|l|c|c|}
\hline Sr. No. & Constraints & WMS & Rank \\
\hline 1. & High cost of initial investment in farm building & 89.17 & 1 \\
\hline 2. & High cost of farm labors & 62.50 & 4 \\
\hline 3. & High cost of equipment's & 80.42 & 3 \\
\hline 4. & Non availability of organized market & 82.92 & 2 \\
\hline 5. & Inadequate transport facilities & 62.08 & 5 \\
\hline
\end{tabular}

Table.4 Administrative constraints faced by rural youth involved in Animal Husbandry

\begin{tabular}{|c|l|c|c|}
\hline Sr. No. & Constraints & WMS & Rank \\
\hline 1. & Lack of subsidies & 89.58 & 4 \\
\hline 2. & Lack of institutional support & 88.33 & 5 \\
\hline 3. & Lack of experts' advice & 92.50 & 1 \\
\hline 4. & No extra incentive for clean milk production & 67.92 & 6 \\
\hline 5. & Inadequate training facilities & 90.83 & 2 \\
\hline 6. & Absence of price fixing agency & 64.58 & 7 \\
\hline 7. & Defunctioning of milk cooperative societies & 90.42 & 3 \\
\hline
\end{tabular}

Table.5 Technical Constraints faced by rural youth involved in Animal Husbandry

\begin{tabular}{|c|l|c|c|}
\hline Sr. No. & Constraints & WMS & Rank \\
\hline 1. & High cost of concentrate & 98.75 & 1 \\
\hline $\mathbf{2 .}$ & High cost of veterinary medicines & 87.92 & 5 \\
\hline $\mathbf{3 .}$ & Shortage of feed \& fodder & 92.08 & 3 \\
\hline $\mathbf{4 .}$ & Non availability of green fodder & 90.42 & 4 \\
\hline $\mathbf{5 .}$ & High cost of crossbreed cow/ improved buffalo & 93.33 & 2 \\
\hline $\mathbf{6 .}$ & Poor services available at AI centre & 81.67 & 6 \\
\hline $\mathbf{7 .}$ & $\begin{array}{l}\text { Inadequate knowledge of scientific feeding of dairy } \\
\text { animals }\end{array}$ & 75.00 & 7 \\
\hline
\end{tabular}

Table.6 Marketing constraints faced by rural youth involved in Animal Husbandry

\begin{tabular}{|c|l|c|c|}
\hline Sr. No. & Constraints & WMS & Rank \\
\hline 1. & Non-remunerative price for milk & 98.75 & 1 \\
\hline 2. & Nonfunctioning milk cooperative societies & 97.92 & 2 \\
\hline 3. & Delay in payment from customers & 88.33 & 3 \\
\hline 4. & Fluctuation of milk production & 70.83 & 4 \\
\hline 5. & Spoilage of milk due to delay in marketing & 65.42 & 5 \\
\hline 6. & Difficulty in distribution of milk in rainy season & 52.50 & 7 \\
\hline 7. & High cost of transportation & 53.75 & 6 \\
\hline
\end{tabular}


It can be concluded that the youth represent the most dynamic and vibrant segment of the population and growing large number of unemployed youth is one of the most daunting problems faced by developed and developing countries. Agriculture sector with limited land is facing difficulty to absorb the young labor force which in turn is giving birth to rural industries to solve rural unemployment and rural migration to cities. Animal Husbandry sector is one of the sector that is taken up by rural youth as activities providing full time self-employment or supplementing the financial resources. The young entrepreneur faces various constraints in running the enterprise i.e. non-remunerative price of milk, non-functioning milk cooperative societies, high cost of concentrate, lack of subsidies as the major constraints. Therefore measures must be adopted to enhance the adoption of animal husbandry technologies by launching new capacity building programme especially targeting rural youth. In order to increase production, it is necessary to impart training on regular basis to youth for adoption of new animal husbandry technologies which can be utilized and adopted by the youth to their full advantage.

\section{Acknowledgement}

The authors thank the Vice Chancellor, DUVASU, Mathura for providing financial assistance and infrastructure to carry out the research work. First author also thanks the young farmers for freely sharing their viewpoint about the dairy farming.

\section{References}

Akash Maske, Amol Patil, Dhananjay Deshmukh, Babulal Kumawat and Manojkumar Pande. 2020. Assessment of Constraints Faced by Dairy Farmers and Livestock Development Officers in Managing Reproductive Disorders in
Parbhani District of Maharashtra, India. Int.J.Curr.Microbiol.App.Sci. 9(07): 1319-1324.

Balaganoormath L, Sangappa, Kadian KS. 2018. Constraints faced by agripreneurs and their clients in management and adoption of dairy enterprise activities in Karnataka state. Journal of Pharmacognosy and Phytochemistry, 7(1): 102-104.

Dubey YK, Sharma ML, Yadaw KN. 2012. Problems faced in adoption of improved dairy farming practices by the dairy farmers of Raipur city. Research Journal of Animal Husbandry and Dairy Science, Volume 3 | Issue 1 | June, 30-33.

Khokhar SR. 2007. A study on adoption of dairy innovations by dairy farm women in Anand District, M.Sc. (Agri.) thesis submitted to department of extension education b. A. College of agriculture Anand Agricultural University Anand.

Kumar GS, Selvakumar KN, Prabu M, Pandian ASS, Valli C, and Kannadhasan MS. 2017. Constraints in Livestock Rearing among Resource Poor Farmers in Rural Tamil Nadu. Asian Journal of Agricultural Extension, Economics \& Sociology 15(2): 1-5, 2017; Article no. AJAEES.31841 ISSN: 2320-7027.

Mande JV. And Thombre BM. 2009. Adoption of cattle rearing practices by dairy cattle owners in Latur district. Journal of Dairying, Foods \& Health Science, 28 (3/4): 176-180.

Meena B.S., Verma H.C., Meena H.R., Singh Amit, Meena D.K. (2015). Field level study on productive and reproductive parameters of dairy animals in Uttar Pradesh, India. Indian Journal of Animal Research, 49(1): 118-122.

Naik D, and Sumangala PR. 2014. Constraints in rural dairy farming in Dharwad and kalaghatgi.Radix international journal 
of research in social science, Volume 3 , Issue 5 .

Panchbhai, G.J., M.F. Siddiqui, M.N. Sawant, A.P. Verma and Parmeswaranaik, J. 2017. Constraints Faced by CoOperative Dairy Farmers in Adoption of Recommended Dairy Management Practices.

Int.J.Curr.Microbiol.App.Sci. 6(3): 1962-1966.

Patel K, Chaudhary GM, Ghasura RS, Aswar BK. 2015. Constraints Faced by Dairy Farm Women in Improved Animal Husbandry Practices of Banaskantha District of North Gujarat. Indian Journal of Hill Farming. 28 (2): 130132.
Rathod PK, Nikam TR, Landge S, Vajreswari S. 2011. Socio-personal profile and constraints of dairy farmers.Karnataka J. Agric. Sci.,24 (4): (619-621).

Singh P, Bhatti JS, Hundal JS and Kansal SK. 2015. Constraints faced by farmers in adoption of dairy as entrepreneurship. Haryana Vet. 54 (1): 67-69.

Varaprasad AR, Raghunandan T, Kumar MK, Prakash MG. 2013. Studies on the socio economic profile and constraints faced by the farmers rearing jersey $\mathrm{x}$ sahiwal cows in Chittoor district of Andhra Pradesh, International Journal of Science, Environment and Technology. 2 (3): 404 - 409.

\section{How to cite this article:}

Sandeep Sharma, Sanjeev Kumar Singh, Amit Singh and Rashmi. 2021. Constraints Faced by the Young Entrepreneurs Involved in Dairying Enterprise in Semi-arid Dholpur District of Rajasthan. Int.J.Curr.Microbiol.App.Sci. 10(01): 735-741.

doi: https://doi.org/10.20546/ijcmas.2021.1001.090 